\section{Introducing the PT Sans and PT Serif typefaces}

Pavel Farář

\begin{abstract}
This article introduces the high quality typefaces PT Sans and PT Serif released by ParaType. They cover many languages written in Latin or Cyrillic scripts.
\end{abstract}

\section{Introduction}

I was looking for some time for a good free font that could be used for both the Czech and Russian languages. This is not so easy as it might seem.

Most fonts containing the Latin alphabet are unsatisfactory for the Czech language due to a single accent - a special type of caron. This accent must be seen in the context of the whole word, not just one letter. We will see more about this later.

Some fonts are usable for the Czech language and do contain a Cyrillic alphabet, but with somewhat questionable quality.

After some time I found PT Sans. It was created by Russian professionals and therefore the high quality of the Cyrillics was no surprise to me. Moreover it was also very good for the Czech language and the font was nice. PT Serif appeared later and I decided to make these fonts available for the $\mathrm{T}_{\mathrm{EX}}$ community.

\section{About the project}

Both these typefaces were designed for the project "Public Types of Russian Federation". This project was founded on the occasion of the anniversary of the reform of the Russian alphabet by Peter the Great in 1708-1710 and was financially supported by the Federal Agency for Press and Mass Communications. The main aim of the project is to make it possible for the people of the Russian Federation to read and write in their native languages.

The idea to create a free font for all people and nationalities of the Russian Federation has existed for a long time. And the reason was simple - the existing fonts that most people could use had some problems. The fonts distributed with operating systems did not cover all languages. Moreover, they were usually done in western countries and this resulted in unsatisfactory quality for the Cyrillic alphabet, especially when used in print, that is, at higher resolutions. There have also been some projects creating free fonts for many languages, but they had similar problems.

People behind this project wanted to avoid all the shortcomings of existing fonts and so they formulated several requirements for the new fonts:
- They should be free of charge, with clear licensing; the usage should not be restricted.

- They should support as many languages as possible.

- They should be created by a professional, native, type designer.

- They should be universal typefaces for a wide range of use.

- They should be of high quality.

- They should be financially supported by the authorities of the Russian Federation.

The fonts were created by the professional font company ParaType by Alexandra Korolkova and Olga Umpeleva under supervision of Vladimir Yefimov. The first font that appeared was PT Sans; one year later came PT Serif, and there are plans for a monospaced font. The fonts are available in TrueType format and also as web fonts.

The work on these fonts took many months and many people helped with this project. Some institutions were asked for their opinions and needs. It was necessary to find as much information about the languages and their characters as possible - the fonts needed to contain letters that the designers had never seen before. Western designers were consulted about the Latin part of the fonts. There was much more work, and all this resulted in very nice professional fonts.

The fonts were first released under ParaType Free Font License, but the company was willing to release them also under other free licenses if needed. Therefore the fonts later appeared also under OFL. Both these licenses are very similar. The fonts can be modified and the modified version can be distributed, but not under the original name without explicit written permission from ParaType.

I have no plans to extend the fonts, I just needed to convert them from TrueType to Type 1 for the best usability in $\mathrm{T}_{\mathrm{EX}}$ and I wanted to keep the original name. So I asked for this permission and I used the fonts released under the original license.

\section{Scripts of minority languages}

The fonts cover all main and most minority languages that are used in the Russian Federation and also many languages of the neighbouring countries. Some of these minority languages are used by very few people and some letters used in these languages are therefore not very common. This makes these fonts uniquely valuable, but it brings some problems at the same time. The problems are mostly related to the fact that there is bad support for some letters.

The first type of problem is the standardization of these letters. Some letters are not included in 
Unicode or the Adobe Glyph List. They therefore have non-standard Unicode values and are located in the private area. This is true not only for Cyrillic, but also for some Latin letters:

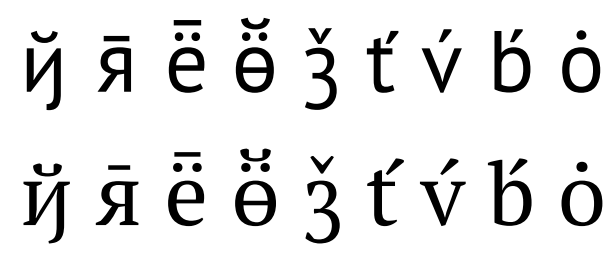

Figure 1: Some non-standard letters

The second type of problem is that some Cyrillic and Latin letters contained in the fonts are not supported by the font encodings in $\mathrm{TE}_{\mathrm{E}}$. This is intentional for some accented Cyrillic letters because there are too many such letters and they can be constructed with quite satisfactory results from the unaccented letter and accent. But this is not true for all letters. Some uncommon Latin letters with the acute accent give very bad results. Compare the following letters with added acute accent to the letters precomposed in the PT fonts (figure 1):

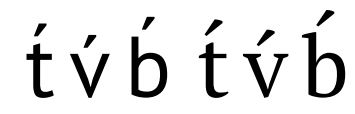

Figure 2: Composing characters with acute

There is another problem in the Cyrillic font encodings. The encodings contain several letters with descender or hook, but none with tail. The letters with tail and descender are somewhat similar, but they are used for different languages.

\section{Д Л Л Л Л Л}

Figure 3: Cyrillic el with tail, descender and hook

For example, the Khanty language should use the Cyrillic letter el with descender, while the Itelmen language uses the same letter with tail. The encoding T2B should cover both these languages, but contains only the letter with descender.

There are several solutions to these problems, but the easiest is certainly the usage of Unicodeaware engines such as $\mathrm{X} \mathrm{H}_{\mathrm{E}} \mathrm{X}$.

Another possibility is to create new font encodings covering all the missing languages - at least one Latin and one Cyrillic. This would take some time just for the PT fonts, and even more if it should be usable also for other fonts. But it would probably not be worth all the effort when there is a different and simpler solution. The future will probably belong to these new Unicode-aware engines.

\section{About the fonts}

Both typefaces have a fairly neutral design, with some modern humanistic features. This allows usage for many purposes and the fonts also have their own modern character.

The fonts can be used for both screen and print. PT Sans has four basic styles, two narrow styles and two caption styles. You can use PT Sans for electronic documents or the Internet, but also for printed matter of general destination. It is also well suitable for communication design like road signs or information boards.

\section{PT Sans Regular \\ PT Sans Italic \\ PT Sans Narrow \\ PT Sans Bold \\ PT Sans Bold Italic \\ PT Sans Narrow Bold \\ PT Sans Caption \\ PT Sans Caption Bold}

Figure 4: The styles of PT Sans

PT Serif has four basic styles and two caption styles. It is suitable for business documents and publications in various fields, including advertising and display typography.

\section{PT Serif Regular $\quad$ PT Serif Bold PT Serif Italic $\quad$ PT Serif Bold Italic PT Serif Caption $\quad P T$ Serif Caption Italic}

Figure 5: The styles of PT Serif

Both PT Serif and PT Sans have true italics. This is not so common, especially for sans serif typefaces. There are more differences between the regular and italic shape in the Cyrillic alphabet.

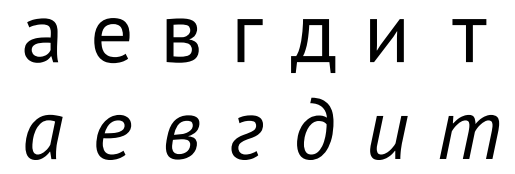

Figure 6: True italics in PT Sans

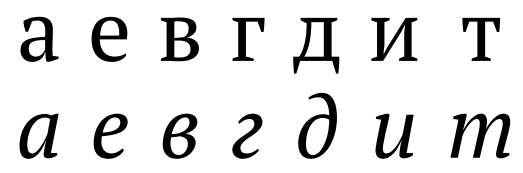

Figure 7: True italics in PT Serif

There is also another thing that is not so common in many fonts: the accents for capital and small 
letters have different shapes. This has a good practical reason - it allows tighter linespacing. The accents for capital letters have smaller height than those for small letters and there are therefore fewer collisions between these accents and the descenders of letters above them.

\section{Šš Éé Ôô Šš Éé Ôô}

Figure 8: Different shapes of accents

Although the families are harmonized and can be used together, PT Sans is not just PT Serif without serifs. For example the letter $g$ is open in PT Sans and closed in PT Serif. The open letterform is suitable for display purposes, the closed form is good for running text.

\section{$\operatorname{gg} \mathbf{g} g g \mathbf{g g}$}

Figure 9: Different shapes of letter g

PT Serif Caption is a font for small sizes. It has the usual changes that improve the readability of small sizes, but the designers did not stop there. They also changed some details like serifs or accents. You could overlook it for small sizes but when you use it at bigger sizes, the differences are quite obvious and you get a font with its own new character.

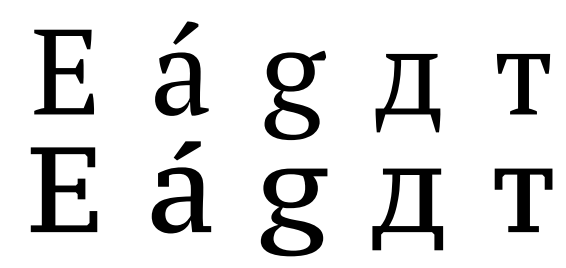

Figure 10: PT Serif and enlarged PT Serif Caption

Although the fonts were designed for the Russian Federation, their coverage of the encoding $\mathrm{T} 1$ is very good; only a few characters such as $\mathrm{D}$ and $\mathrm{y}$ are missing. Therefore the fonts can be used for most Latin-based European languages. On the other hand, not all Cyrillic based languages are supported and the Cyrillic encodings in $\mathrm{TEX}_{\mathrm{X}}$ are not fully covered. Again, just few characters are missing.

The fonts have over 700 characters, but they do not have everything. They have only ligatures fi and $\mathrm{fl}$ and there is only the Cyrillic em-dash that is somewhat shorter than the English one.

\section{About the caron}

I would like to say also some words about one usually misunderstood accent. This is the special type of caron used in small letters with ascenders. The usual type of caron could not be in the same height as it is in the letters without ascenders. Therefore a special accent is used that looks more like an apostrophe than like the usual caron.

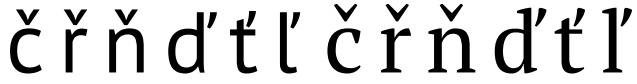

Figure 11: Different shapes of caron

It is important to realize that this is not an apostrophe. It is usually more subtle and the most important difference is that words containing this accent should be compact, whereas apostrophe quite clearly separates the letters on the left from those on the right.

\section{žlutoučká lat́ka it's apostrophe}

Figure 12: Caron and apostrophe in PT Sans

\section{dáblova lodkka Fred's book}

Figure 13: Caron and apostrophe in PT Serif

It looks very easy and it certainly is, but nevertheless most fonts are bad in this respect - and it is not just a $\mathrm{T}_{\mathrm{E} X} \mathrm{X}$-related problem.

See also the Slovak language sample in section B.1 where you can see the letter $l$ with caron.

\section{Summary}

The described typefaces have some properties that can make them a very useful part of $\mathrm{TE}_{\mathrm{E}} \mathrm{X}$ distributions:

- They are of professional quality.

- They are universal typefaces and can be used for many purposes.

- They cover many western and central European languages and they can hardly be surpassed for coverage of the languages of the Russian Federation.

The fonts are ideal for multilingual texts where you need consistent appearance for all languages. The coverage of many languages makes the fonts somewhat similar to projects like $\mathrm{T}_{\mathrm{EX}}$ Gyre, but they also contain Cyrillic letters. 


\section{A PT Sans Samples}

\section{A.1 English}

All human beings are born free and equal in dignity and rights. They are endowed with reason and conscience and should act towards one another in a spirit of brotherhood.

All human beings are born free and equal in dignity and rights. They are endowed with reason and conscience and should act towards one another in a spirit of brotherhood.

\section{A.2 Serbian}

Сва људска бића рађају се слободна и једнака у достојанству и правима. Она су обдарена разумом и свешћу и треба једни према другима да поступају у духу братства.

Сва људска бића рађају се слободна и једнака у достојанству и правима. Она су обдарена разумом и свешћу и треба једни према другима да поступају у духу братства.

\section{A.3 French}

Tous les êtres humains naissent libres et égaux en dignité et en droits. Ils sont doués de raison et de conscience et doivent agir les uns envers les autres dans un esprit de fraternité.

\section{A.4 Spanish}

Todos los seres humanos nacen libres e iguales en dignidad y derechos y, dotados como están de razón y conciencia, deben comportarse fraternalmente los unos con los otros.

\section{A.5 Czech}

Všichni lidé se rodí svobodní a sobě rovní co do důstojnosti a práv. Jsou nadáni rozumem a svědomím a mají spolu jednat $v$ duchu bratrství.

\section{A.6 Ukrainian}

Всі люди народжуються вільними і рівними у своїй гідності та правах. Вони наділені розумом і совістю і повинні діяти у відношенні один до одного в дусі братерства.

\section{B PT Serif Samples}

\section{B.1 Slovak}

Všetci ludia sa rodia slobodní a sebe rovní, čo sa týka ich dôstojnosti a práv. Sú obdarení rozumom a svedomím a majú navzájom jednat v bratskom duchu.

Všetci ludia sa rodia slobodní a sebe rovní, čo sa týka ich dôstojnosti a práv. Sú obdarení rozumom a svedomím a majú navzájom jednat'v bratskom duchu.

\section{B.2 Russian}

Все люди рождаются свободными и равными в своем достоинстве и правах. Они наделены разумом и совестью и должны поступать в отношении друг друга в духе братства.

Все люди рождаются свободными и равными в своем достоинстве и правах. Они наделены разумом и совестью и должны поступать в отношении друг друга в духе братства.

\section{B.3 German}

Alle Menschen sind frei und gleich an Würde und Rechten geboren. Sie sind mit Vernunft und Gewissen begabt und sollen einander im Geist der Brüderlichkeit begegnen.

\section{B.4 Danish}

Alle mennesker er født frie og lige i værdighed og rettigheder. De er udstyret med fornuft og samvittighed, og de bør handle mod hverandre i en broderskabets ånd.

\section{B.5 Polish}

Wszyscy ludzie rodzą się wolni i równi pod względem swej godności i swych praw. Są oni obdarzeni rozumem i sumieniem i powinni postępować wobec innych w duchu braterstwa.

\section{B.6 Hungarian}

Minden emberi lény szabadon születik és egyenlő méltósága és joga van. Az emberek, ésszel és lelkiismerettel bírván, egymással szemben testvéri szellemben kell hogy viseltessenek.

\section{B.7 Abkhaz}

Дарбанзаалак ауаєы дшоуп ихы дақәитны. Ауаа зегь зинлеи патулеи еикароуп. Урт ирымоуп ахшыси аламыси, дара дарагь аешьеи аешьеи реипш еизыказароуп.

\section{References}

[1] Omniglot. http://www .omniglot.com.

[2] ParaType. English: http://www .paratype.com; Russian: http://www. paratype.ru.

[3] Unicode Consortium. http://unicode.org.

$$
\begin{aligned}
& \diamond \text { Pavel Farář } \\
& \text { Prague, Czech Republic } \\
& \text { pavel dot farar (at) centrum dot cz }
\end{aligned}
$$

